\title{
Prevalence and Risk Factors Associated with
}

\section{Haemoparasitosis in Village Chickens (Gallus Gallus Domesticus) in Gombe State, Nigeria}

\section{Lawal JR, Ibrahim UI, Biu AA and Musa HI}

${ }^{1}$ Department of Veterinary Medicine, University of Maiduguri, Nigeria

${ }^{2}$ Department of Veterinary Parasitology and Entomology, University of Maiduguri, Nigeria

${ }^{3}$ Department of Veterinary Public Health and Preventive Medicine, University of Maiduguri, Nigeria

*Corresponding author: Jallailudeen Rabana Lawal, Department of Veterinary Medicine, Faculty of Veterinary Medicine, University of Maiduguri, Maiduguri, Borno State, Nigeria, Email: rabanajallailudeen@yahoo.com

\section{Abstract}

The present study was conducted between November, 2016 and September, 2017, aimed to determine the prevalence and risk factors associated with haemoparasitosis in village chickens in Gombe State, Nigeria. Blood samples were collected from a total of 1820 village chickens and Giemsa stained thin blood smears were microscopically examined for the presence of haemoparasites. Results revealed an overall prevalence of $19.6 \%$ of three genera of avian haemoparasites in a single and mixed infection. Amongst the haemoparasites encountered, Plasmodium (13.9\%) was the most prevalent followed by Haemoproteus (2.6\%) and Leucocytozoon (0.4\%) in single infection, while the prevalence of mixed infection with Plasmodium + Haemoproteus was 2.6\%. Higher prevalence rates were recorded in cocks (28.5\%) compared to hens (8.9\%), as well as in adults (23.0\%) compared to the growers (11.0\%) village chickens. The prevalence rates was found to be higher in the rainy (39.3\%) compared to cold dry (12.5\%) and hot dry (7.7\%) seasons of the study period. The difference in prevalence of haemoparasites among sex, age groups, and season was statistically significant (<0.0001). In conclusion, haemoparasites exist among village chickens flocks in Gombe State, Nigeria probably due to the presence of vectors and inadequate practice of biosecurity measures. It is therefore, recommended that awareness should be created on the prevalence of haemoparasites, further researches involving molecular characterization of haemoparasites should be carried out and village chicken farmers should be educated on the need for maintenance proper biosecurity measures on their farms.

Keywords: Haemoparasites; Plasmodium; Haemoproteus; Leucocytozoon; Village Chickens; Gombe State 


\section{Open Access Journal of Veterinary Science \& Research}

\section{Introduction}

Village chickens are among the domesticated village poultry species raised extensively in small numbers with very little capital investment in their management and are seldom given special attention in terms of feeding, housing and health care [1,2]. They usually scavenge for feed and water around households, rubbish dumps or stagnant water in most developing countries, thus predisposed to agents of infectious diseases as well as vectors of parasitic infections [3-5]. Diseases are the most important limiting factors to village chickens productivity in most African developing countries [2,6-8]. Parasitic diseases are among the infections that usually lead to severe loses in chicken productivity worldwide $[6,9]$.

Haemosporidians (Sporozoa: Haemosporida) are a group of endoparasitic protists that inhabit a broad range of host species of amphibians, reptiles, birds and mammals [5,10-12]. These protozoans are worldwide in distribution and are spread through a wide range of habitats and geographical regions $[13,14]$. Haemoparasites show a complex life cycle which requires arthropod vectors for disease transmission [15]. The abundance of these vectors may depend on some climatic conditions including weather $[16,17]$. The prevalence of parasitosis in any geographical region will likely depend on environmental conditions such as temperature, humidity and rainfall that will in turn impact the numbers and distribution of their insect vectors [18].

More than 200 species of avian haemoparasites have been reported worldwide, and have been classified broadly into four distinct genera viz: Plasmodium, Haemoproteus, Leucocytozoon and Hepatocystis [19-21]. The vectors for these parasites are exclusively bloodsucking dipteran insects belonging to 17 genera [22-24]. It has been revealed that avian malaria is caused by parasites of the genera Leucocytozoon, Plasmodium and Haemoproteus $[25,26]$. Trypanosomes, unrelated to the haemosporidians, are also widely encountered in avian blood and can be transmitted by several insect species, most typically through the ingestion of the vector, such as the Culex mosquitoes $[27,28]$. Nematode microfilariae are also common in avian blood [29]. Other vector-borne blood parasites of birds include sporozoan parasites of the genera Hepatozoon, Babesia and Atoxoplasma.

Haemoparasites have been reported to have significant effects on the health status of infected birdsby reducing their survival [25], body condition [30-32], and productivity [33-36]. These effects further leads to impaired immunological responses and decreased survival rate [37]. Severe infections by avian haemoparasites can lead to death [38,39] and could involve different physio-pathological phenomena such as anemia, thrombocytopenia and inflammation $[39,40]$.

The investigation of haemoparasites from infected birds may be done using microscopic identification of the parasites in blood smears [25], as well as through the amplification and sequencing of DNA [14,41,42]. Some studies have shown that both methods can have similar sensitivities for detection of these haemoparasites $[14,32,43$,$] .$

Generally, few studies have reported the prevalence of haemoparasitosis in village chickens in Nigeria and other developing nations $[23,44-52]$.

The present study aimed to determine the prevalence and the risk factors associated with haemoparasitosis in village chickens (Gallus gallus domesticus) in Gombe State, Nigeria.

\section{Materials and Methods}

\section{Study Area}

This study was carried out in Gombe State, Northeastern Nigeria. The state is situated in the North Eastern zone of Nigeria and shares boundaries with Bauchi, Taraba, Adamawa, Yobe and Borno states. The state has Eleven Local Government Areas that are populated by ethnic groups including Hausa, Fulani, Tera, Waja, Tangale and Bolawa among others. Gombe state is located between latitude $9^{\circ} 30^{\prime}$ and $12^{\circ} 3^{\prime} \mathrm{N}$ and longitude $8^{\circ} 45^{\prime}$ and $11^{\circ} 45^{\prime} \mathrm{E}$ [53]. The state has a mean annual rainfall of $818.5 \mathrm{~mm}$, with a mean maximum temperature of $37^{\circ} \mathrm{C}$ and a mean minimum temperature of $12^{\circ} \mathrm{C}$. The hottest months are March - May $\left(40^{\circ} \mathrm{C}\right)$, and the coldest period is from December to February (harmattan). The state is also characterized with relative humidity of $90 \%$ in August and 10\% in December. The climatic and edaphic factors favour crop and livestock agriculture. The major economic activities of the people of Gombe State include crop and livestock production as well as trading. The total poultry population in Gombe State is approximately 508, 305 comprising 462,000 backyard poultry and 46,305 exotic poultry [54]. Rural and urban areas within Eight (8) out of the Eleven (11) Local Government Areas of the state was visited for sample collection viz: Gombe, Akko, Funakaye, Kwami, Dukku, Yamaltu-Deba, Kaltungo and Balanga Local Government Areas. Non-probability 
convenience sampling method was used with emphasis on areas with large populations of village chickens.

\section{Sampling Period}

Sampling was carried out from November, 2016 to September, 2017 within three (3) seasons viz, the cold dry season (November-February), hot dry season (MarchMay) and rainy season (June-September). All study locations were visited for samples and other data collection within these study periods.

\section{Target Population}

At least three (3) major live birds markets and village poultry farmers' households that rears relatively large population of village chickens and willing to volunteer their village chickens for blood sampling were visited for blood sample collections.

\section{Sampling Method for Birds}

Each sampled bird was properly restrained and prepared for blood sample collection. Using a sterile $5 \mathrm{ml}$ syringe and 23 gauge needles, $3-4 \mathrm{ml}$ of blood sample were collected directly from brachial vein (wing vein) of each sampled chicken using the procedure described by Chesebrough and Rukhsana [55,56]. Each blood samples was immediately dispensed into a EDTA anticoagulant bottle. All samples were labeled appropriately and transported to the Department of Veterinary Parasitology and Entomology laboratory, Faculty of Veterinary Medicine, University of Maiduguri in ice pack container.

\section{Preparation of Blood Smears for Identification of Haemoparasites, Parasitological Examination and Detection of Haemoparasites}

Thin smears were made from each blood sample and allowed for few minutes to air dry and then labeled appropriately. The slides were fixed with methanol and stained with diluted $10 \%$ Giemsa stain according to the standard procedures described by Zajac and Conboy [57]. The slides were later viewed at low magnification $(40 \times)$ and at high magnification $(100 \times)$ using microscope under oil immersion for 10-15 min for the presence of intracellular blood parasites gametocytes as previously described by Valkiūnas, Valkiūnas and Akinpelu $[15,58,59]$. Sample was considered negative when no parasite is detected after examining 100 microscopic fields.

\section{Statistical Analysis}

Data generated from the study were initially analyzed in Microsoft office Excel version 2011 to obtain percentages and prevalence of haemoparasites. The prevalence $(\mathrm{P})$ in percentage was calculated using the formula $P=n / N$, where $n$ is the number of positive samples analyzed at that point in time and $\mathrm{N}$ is the total number of chickens sampled at that point in time [60]. The SPSS statistical software version 22 was used for both Fisher's exact test and Chi-square statistical analysis. The statistically significant association between the risk factors and the infection was determined at $\mathrm{p}<0.05$.

\section{Results}

The results of microscopy examinations of blood smears for the presence of avian haemoparasites in village chickens in Gombe State revealed that out of 1820 total blood samples examined 356 blood samples were found to be infected by avian haemoparasites with an overall prevalence rate of $19.6 \%$ (17.8 - 21.5 at $95 \%$ confidence interval). The prevalence of avian haemoparasites were found to be higher among chickens sampled from poultry farmers' households $236(19.8 \%)$ compared to those sampled from live bird markets 120 $(19.1 \%)$. Although, there was no statistical significant ( $\mathrm{p}>$ $0.05 ; \chi^{2}=0.77$ ) association of prevalence with source of the chickens as shown in (Table 1).

\begin{tabular}{|c|c|c|c|}
\hline \multirow{2}{*}{} & \multicolumn{2}{|c|}{ Chicken Source } & \multirow{2}{*}{ All Chickens } \\
\cline { 2 - 3 } & Markets & Households & 1820 \\
\hline Number Examined & 628 & 1192 & 356 \\
\hline Number Infected & 120 & 236 & $19.6(17.8-21.5) \dagger$ \\
\hline Prevalence (\%) & $19.1^{*}$ & $19.8^{*}$ & \\
\hline
\end{tabular}

Table 1: Chicken source-specific prevalence of avian haemosporidian parasites in village chickens in Gombe State, Nigeria.

${ }^{*}$ No significant $(p>0.05)$ association of prevalence with source of chickens; $\uparrow 95 \%$ confidence interval. 
Moreover, results of the prevalence of haemoparasites genera detected in the infected village chickens in Gombe State revealed that Plasmodium (13.90) was the most prevalent haemoparasites followed by mixed infection of
Plasmodium+Haemoproteus (2.64\%) and Haemoproteus $(2.58 \%)$ while Leucocytozoon $(0.44 \%)$ was the least prevalent haemoparasites detected (Table 2).

\begin{tabular}{|c|c|c|c|}
\hline & Number of Chickens Infected (N= 1820) & Percentage (\%) (n = 356) & Prevalence (\%) \\
\hline Plasmodium & 253 & 71.07 & 13.9 \\
\hline Haemoproteus & 47 & 13.2 & 2.58 \\
\hline Leucocytozoon & 8 & 2.25 & 0.44 \\
\hline Plasmodium + Haemoproteus & 48 & 13.48 & 2.64 \\
\hline TOTAL & 356 & 100 & 19.56 \\
\hline
\end{tabular}

Table 2: Prevalence of Haemosporidian parasites genera in Village Chickens in Gombe State, Nigeria.

$\mathrm{N}=$ Total Number of village chickens examined and sampled during study period.

$\mathrm{n}=$ Total Number of village chickens infected with haemoparasites during study period.

Table 3 depicts results of sex - specific prevalence of avian haemoparasites in village chickens in Gombe State. Out of 623 males and 569 female village chickens blood samples collected from the poultry farmers' households, avian haemoparasites were found to be higher in the male $188(30.2 \%)$ compared to the female $48(8.4 \%)$ chickens. There was statistical significant $\left(\mathrm{p}<0.05 ; \chi^{2}=87.16\right.$ at $95 \%$ confidence interval) association among sex of the chickens sampled from households. Also, Out of 366 males and 262 female village chickens blood samples collected from the live birds markets, avian haemoparasites were also found to be higher in the males
$94(25.7 \%)$ compared to the female $26(9.9 \%)$ chickens. There was also statistical significant $\left(\mathrm{p}<0.05 ; \chi^{2}=23.53\right.$ at $95 \%$ confidence interval) association of sex among of chickens sampled from live birds markets. Out of the total 989 blood samples collected from males and 831 collected from female village chickens in Gombe State, the prevalence of avian haemoparasites were found to be higher in the males $282(28.5 \%)$ compared to the female $74(8.9 \%)$ village chickens. There was statistical significant $\left(\mathrm{p}<0.05 ; \quad \chi^{2}=109.11\right.$ at $95 \%$ confidence interval) association among sex of chickens sampled in Gombe State.

\begin{tabular}{|c|c|c|c|c|}
\hline Sex & Number Chickens Examined & Number Chickens Infected & \multicolumn{1}{l|}{ Prevalence (\%) } & P - Value \\
\hline \multicolumn{5}{|c|}{ Household Chickens } \\
\hline Male & 623 & 188 & $30.2^{\mathrm{a}}(26.7-33.9) \dagger$ & $\mathrm{p}<0.0001$ \\
\hline Female & 569 & 48 & $8.4^{\mathrm{b}}(6.4-11.0) \dagger$ & \\
\hline \multicolumn{5}{|c|}{ Market Chickens } \\
\hline Male & 366 & 94 & $25.7^{\mathrm{a}}(21.5-30.4) \dagger$ & $\mathrm{p}<0.0001$ \\
\hline Female & 262 & 26 & $9.9^{\mathrm{b}}(6.9-14.1) \dagger$ & \\
\hline \multicolumn{5}{|l|}{} \\
\hline Male & 989 & 282 & $28.5^{\mathrm{a}}(25.8-31.4) \dagger$ & $\mathrm{p}<0.0001$ \\
\hline Female & 831 & 74 & $8.9^{\mathrm{b}}(7.2-11.0) \dagger$ & \\
\hline
\end{tabular}

Table 3: Sex-specific prevalence of avian haemoparasites in village chickens in Gombe State, Nigeria. a,b Different superscripts indicate significant $(\mathrm{p}<0.05)$ difference in age-specific prevalence; $\uparrow 95 \%$ confidence interval.

Table 4 shows results of age-prevalence of haemoparasites in village chickens in Gombe State, Nigeria. Out of 802 adults and 390 grower village chickens blood samples collected from the poultry farmers' households, the prevalence of avian haemoparasites were found to be higher in the adult 195 (24.3\%) compared to the growers $41(10.5 \%)$ chickens. There was statistical significant $\left(\mathrm{p}<0.05 ; \chi^{2}=30.61\right.$ at $95 \%$ confidence interval) association among age group of chickens sampled from poultry farmers' households. However, Out of 517 adults and 111 grower chickens blood samples collected from the live birds markets, the prevalence of avian haemoparasites were also found to be higher in the adults 106 (20.5\%) compared to the growers $14(12.6 \%)$ chickens. There was no statistical significant ( $p>0.05 ; \chi^{2}=3.19$ at $95 \%$ confidence interval) association among age of the chickens sampled from live birds markets. Out of the total 1319 blood samples 
collected from adults and 501 from grower chickens, avian haemoparasites were found to be higher in the adults $301(23.0 \%)$ compared to the grower $55(11.0 \%)$ chickens. However, there was statistical significant ( $\mathrm{p}<0.05 ; \chi^{2}=31.61$ at $95 \%$ confidence interval) association among age of chickens sampled in Gombe State.

\begin{tabular}{|c|c|c|c|c|}
\hline Age Group (Months) & Number Examined & Number Infected & Prevalence (\%) & P-Value \\
\hline \multicolumn{7}{|c|}{ Household chickens } \\
\hline Adult (>5) & 802 & 195 & $24.3^{\mathrm{a}}(21.5-27.4) \dagger$ & $\mathrm{p}<0.0001$ \\
\hline Growers (3-4) & 390 & 41 & $10.5^{\mathrm{b}}(7.8-14.0) \dagger$ & \\
\hline \multicolumn{5}{|c|}{ Market chickens } \\
\hline Adult (> 5) & 517 & 106 & $20.5^{\mathrm{a}}(17.2-24.2) \dagger$ & $\mathrm{p}=0.0742$ \\
\hline Growers (3-4) & 111 & 14 & $12.6^{\mathrm{a}}(7.7-20.1) \dagger$ & \\
\hline \multicolumn{7}{|c|}{ All chickens } \\
\hline Adult (> 5) & 1319 & 301 & $23.0^{\mathrm{a}}(20.6-25.2) \dagger$ & $\mathrm{p}<0.0001$ \\
\hline Growers (3-4) & 501 & 55 & $11.0^{\mathrm{b}}(8.5-14.0) \dagger$ & \\
\hline
\end{tabular}

Table 4: Age-specific prevalence of avian haemoparasites in village chickens in Gombe State, Nigeria.

a,b Different superscripts indicate significant $(\mathrm{p}<0.05)$ difference in age-specific prevalence; $\uparrow 95 \%$ confidence interval.

Table 5 illustrates results of season-specific prevalence of haemoparasites in village chickens in Gombe State, Nigeria. Out of 380 village chickens sampled during the cold dry season, 432 in the hot dry and 380 sampled during the rainy season from the poultry farmers' households, the prevalence of avian haemoparasites were found to be higher during the rainy season $150(39.5 \%)$ compared to cold dry $53(14.0 \%)$ and the hot dry $33(7.6 \%)$ season. There was statistical significant $\left(p<0.05 ; \quad \chi^{2}=141.06\right.$ at $95 \%$ confidence interval) association among the three seasons of sampling and the prevalence rates. Moreover, out of 210 village chickens sampled during the cold dry season, 205 in the hot dry and 213 sampled during the rainy season from the live birds markets, the prevalence of avian haemoparasites were found to be higher during the rainy season $83(39.0 \%)$ followed by the cold dry 21 (10.0\%) and the hot dry $16(7.8 \%)$ season. There was also statistical significant $\left(\mathrm{p}<0.05 ; \chi^{2}=2.56\right.$ at $95 \%$ confidence interval) association among season of sampling and prevalence rates. Out of the total 590 blood samples collected during the cold dry season, 637 in the hot dry and 593 blood samples collected during the rainy season, the prevalence of avian haemoparasites were found to be higher during the rainy season 233 (39.3\%) followed by cold dry $74(12.5 \%)$ and the hot dry $49(7.7 \%)$ season. There was also statistical significant $\left(\mathrm{p}<0.05 ; \chi^{2}=222.22\right.$ at $95 \%$ confidence interval) association among season of sampling and prevalence rates.

\begin{tabular}{|c|c|c|c|c|}
\hline Season & Number Chickens Examined & Number Chickens Infected & Prevalence (\%) & P - Value \\
\hline \multicolumn{5}{|c|}{ Household Chickens } \\
\hline Cold Dry & 380 & 53 & $14.0^{\mathrm{a}}$ & $\mathrm{p}<0.0001$ \\
\hline Hot Dry & 432 & 33 & $7.6^{\mathrm{b}}$ & \\
\hline Rainy & 380 & 150 & $39.5^{c}$ & \\
\hline \multicolumn{5}{|c|}{ Market Chickens } \\
\hline Cold Dry & 210 & 21 & $10.0^{\mathrm{a}}$ & $\mathrm{p}<0.0001$ \\
\hline Hot Dry & 205 & 16 & $7.8^{\mathrm{b}}$ & \\
\hline Rainy & 213 & 83 & $39.0^{c}$ & \\
\hline \multicolumn{5}{|c|}{ All Chickens } \\
\hline Cold Dry & 590 & 74 & $12.5^{\mathrm{a}}$ & $\mathrm{p}<0.0001$ \\
\hline Hot Dry & 637 & 49 & $7.7^{b}$ & \\
\hline Rainy & 593 & 233 & $39.3^{c}$ & \\
\hline
\end{tabular}

Table 5: Season-specific prevalence avian haemoparasites in village chickens in Gombe State, Nigeria. $a, b, c$ Different superscripts indicate significant $(p<0.05)$ difference in season-specific prevalence. 


\section{Open Access Journal of Veterinary Science \& Research}

\section{Discussion}

The results of this present study revealed the presence of avian haemoparasites in village chickens sampled from both poultry farmers' households and live birds' markets within the study areas. Although, the prevalence of haemoparasites in village chickens sampled from poultry farmers' households (19.8\%) were found to be higher than in village chickens sampled from live birds' markets (19.1\%). However, the different in the prevalent rates between the study sites was not statistically significant ( $\left.p>0.05 ; \chi^{2}=0.77\right)$ at $95 \%$ confidence interval. This finding implies that the chances at which village chickens could be found infected with avian haemoparasites in poultry farmers' households and as well as in live birds' markets share similar opportunities of infections, especially in the presence of the parasites and the abundance of their arthropod vectors. Moreover, village chickens sold in live birds' market are usually source from several households from communities far and near the market, and farmers also purchase chickens for restocking or breeding from live birds' vendors in the markets. This practice plays a vital role in the transmission cycles and maintenance of infectious diseases among susceptible hosts. The overall prevalence of avian haemoparasites in village chickens recorded in the present study was found to be $19.6 \%$. This finding supported the studies of Karamba, et al. [61] who have reported $19.56 \%$ prevalent rate of avian haemoparasites in village chickens in Kano State, Nigeria, but the result of the present study is higher than the findings of Usmana, et al. [62] who have reported $12.0 \%$ in Sokoto State as well as Igbokwe, et al. [63] and Lawal, et al. [64]. Who have reported $11.4 \%$ and $17.0 \%$ in Maiduguri, Borno State respectively? However, the prevalence rate of avian haemoparasites in village chickens recorded in this present study is lower than $26.4 \%$ recorded in Ibadan, Oyo State [47] and $46.7 \%$ in Owerri, Imo State [65]. These variations in the prevalence rates might be attributed to difference in sample sizes, effort of sampling, season of samples collections, geographical regions, and methods employed for diagnosis as well as abundance of arthropod vectors. Moreover, higher prevalence rates of avian haemoparasites in village chickens have also been documented in some parts of Africa such as $43.4 \%$ in Ethiopia [66], 79.2\% in Kenya, [51] $71.0 \%$ and $79.1 \%$ in Malawi by Njunga and Lutz et al. [46,67] respectively, $61.9 \%$ in Uganda, [15] $35.0 \%$ in Ghana, [44] 32.0\% in Zimbabwe [45]. Other similar study from different parts of the world have also reported varying prevalence rates of avian haemoparasites in village chickens, such as Naqvi, et al. [68] who have recorded $69.0 \%$ in Punjab,
Pakistan, Nath and Bhuiyan [69] as well as Momin, et al. [70] have reported $34.5 \%$ and $45.8 \%$ in Bangladesh respectively, $42.0 \%$ in Philippine $[71,72]$ have recorded $34.0 \%$ in India and Abdullah [9] reported $78.2 \%$ in Iraq. These findings revealed the occurrence of haemoparasitosis in scavenging village chickens from different parts of the world.

The results of the present study have discovered $19.56 \%$ overall prevalent rate of three genera of haemoparasites in village chickens viz: Plasmodium, Haemoproteus and Leucocytozoon in a single infection while mixed infection with Plasmodium+Haemoproteus. Similar previous studies have reported the occurrence of these haemoparasites at varying prevalence rates in village chickens in developing countries including Nigeria $[23,64,67-69,71,73]$ The prevalence of Plasmodium (13.9\%) encountered in village chickens in Gombe, Gombe State during this present study is higher than $11.4 \%$ reported in Maiduguri, Borno State Northeastern Nigeria [63] and 12.0\% reported in Sokoto, Sokoto State Northwestern Nigeria [62] but lower than $33.3 \%$ in Owerri, Imo State Southeastern Nigeria [65] and 32.0\% in Ibadan, Oyo State Southwestern Nigeria [47].

The variation in the prevalent rates might be associated with differences in management system and abundance of vectors. The prevalence rate of mixed infection with Plasmodium + Haemoproteus (2.64\%) reported in the present study is lower than 3.5\% and $47.4 \%$ reported by Sabuni, et al. and Hasson $[51,73]$ respectively while Nath and Bhuiyan [69] have reported mixed infection of Plasmodium specie and Haemoproteus specie $(0.5 \%)$ which is lower than that of the present study. The findings of the present study also revealed $2.6 \%$ prevalence of Haemoproteus in village chickens in Gombe State. This finding is higher than $1.3 \%$ and $2.5 \%$ reported by Sadiq, et al. [47] from Ibadan and Bangladesh respectively. The prevalence of Haemoproteus in village chickens reported in this present study is lower than $23.3 \%$ by Islam, et al. [74] in Bangladesh and $13.2 \%$ by Hasson [73] in Iraq. These variations might be due to the geographic distribution, management systems, and abundance of vectors. The findings of the present study revealed $0.4 \%$ prevalence of Leucocytozoon in village chickens in Gombe State. This finding is lower than $20.0 \%$ reported by Sadiq, et al. [47] in Ibadan and $8.9 \%$ by Opara, et al. [75] in Owerri of Nigeria. However, in some parts of Africa, Mbuthia, et al. [76] have reported 31.6\% in Kenya while Etisa, et al. [66] reported $9.6 \%$ in Ethiopia. These findings indicate the occurrence of suitable vectors for the transmission of the genus Leucocytozoon amongst 


\section{Open Access Journal of Veterinary Science \& Research}

village chickens in Africa. Low prevalence of Leucocytozoon in village chickens as single infection detected in the present study compared to results from other parts of Africa may be due to sparse abundance of the arthropod vectors capable of transmitting the parasites in the present study area.

Considering the sex-specific prevalence as a risk factor associated with the prevalence of avian haemoparasites in village chickens in Gombe State, the results of the present study revealed higher prevalence of haemoparasites in males $(28.5 \%)$ chickens compared to the females $(8.9 \%)$ and the difference in the age-specific prevalence rates at $95 \%$ confidence interval was statistically significant $(\mathrm{P}<0.0001)$. This result might be associated with the anatomically larger comb and wattle in cocks, which are well vascularized. This may attract blood sucking arthropods for blood meal during which they transmit haemoparasites to the host. The finding of the present study agreed with Opara, et al. [64] Lawal, et al. [64] who have also reported the occurrence of high prevalence of avian haemoparasites in males than in the female chickens in Owerri and Maiduguri, Nigeria respectively. The finding of the present study coincides with previous report by Sabuni, et al. [51] in Kenya, Nath, et al. and Hasan, et al. [77,78] in Bangladesh, Etisa, et al. [66] in Ethiopia who have also reported high prevalence of avian haemoparasites in cocks of village chickens compared to the hens in their various studies. However, Naqvi, et al. [68] in Pakistan Sehgal, et al. [49] in Uganda and Cameroon, Hasson [73] in Iraq and Nath and Bhuiyan [69] in Bangladesh have indicated that the hens of village chickens were more infected with avian haemoparasites than the cocks. There are usually conflicting reports on the occurrence and impact of sex on prevalence rate of different avian haemoparasites in several species of birds $[19,79,80]$.

Although, several endogenous and exogenous factors may have an accumulative influence on the parasitisation of both sexes of the village chickens by these parasites, such as host's hormones and humoral compounds, age and nutritional state, behaviour and habits, as well as the season of the year and ecological and physical features of the regions [73]. However, Lloyd [81] as cited by Naqvi, et al. [68] and Hasan, et al. [78] have reported that the exact cause of higher prevalence in female birds cannot be explained but in general higher level of prolactin and progesterone suppress the immune system of the individual and make the female individual more susceptible to parasitic infections.
The present study also considered age - specific prevalence of avian haemoparasites in village chickens in the study areas. The result shows higher prevalence of haemoparasites in adult (23.0\%) chickens compared to growers $(11.0 \%)$ and the difference in the age-specific prevalence rates at $95 \%$ confidence interval was statistically significant $(\mathrm{P}<0.0001)$. This finding might be attributed to the fact adult village chickens frequently roam far distances during scavenging and chasing/searching for mating mates, at which times they may get expose to arthropods vectors, while the younger chickens usually found roaming near their owners compound or somewhere safe away from predators. Moreover, an adult village chicken seems to have more prominent and fully grown comb and wattle which are easily parasitized by the blood sucking arthropods vectors. This finding concurs with similar study of Abdul Momin, et al. and Etisa, et al. [70,66] who have also reported significantly higher prevalence of avian haemoparasites in adult chickens than grower in Bangladesh and Ethiopia respectively. However, the finding of the present study is inconsistent with that of Sabuni, et al. and Naqvi, et al. [51,68].

Who have reported highest prevalence of avian haemoparasites in growers than adult chickens in Kenya and Pakistan respectively, although the prevalence rates was not statistically significant $(P>0.05)$. Several studies on avian haemoparasites have demonstrated that adult domesticated birds are more susceptible to haemoparasitosis [74,78,82,83], while some authors indicated that younger birds have a greater prevalence of infection by various groups of haemosporidians [84,85]. Other authors have showed that there were no differences in the prevalence of bird infections in different age groups $[86,87]$. Occurrence of higher prevalence of avian haemoparasites in adult birds may also be attributed to long time exposure to the arthropod borne infections by adult scavenging birds [88-90]. Moreover, Thull and 0 Brien, as cited by Hasan, et al. [91,78] indicated that another cause might be owing to absence of active transmission of malaria parasite from adult to young birds.

The present study was conducted throughout the three seasons of the year (rainy, hot dry, cold dry season). Therefore, the study also considered the season-specific prevalence of avian haemoparasites in village chickens in Gombe State, Nigeria. The results revealed higher prevalent rates of haemoparasites in village chicken during the rainy season (39.3\%) followed by the cold dry $(12.5 \%)$ season and the hot dry season (7.7\%). The 
difference in the season - specific prevalence rates at 95\% confidence interval was statistically significant $(\mathrm{P}<0.0001)$. The finding might be associated with fact that the rainy season is usually the most favourable season that provides conducive weathers conditions (including temperature and humidity) for optimum breeding of most arthropod vectors such as mosquitoes and other flies. This finding is evidenced by the high prevalence of many arthropod vector (mosquitoes, ticks) borne blood parasitic infections such as malaria, trypanosomosis in human and animal populations during the rainy season in Nigeria [92-98]. More so, increased breeding of arthropod vectors including mosquitoes during rainy season could be as a result of rampant bushes/vegetation from crop farming activities, stagnated pool of water resulting from poor drainage system, optimum humidity and temperature required for egg hatching. While, during the cold dry season arthropods and flies seek for warm places and find refuge within warmer human settlements seeking for blood meal from humans and other livestock including the chickens thereby causing pockets of blood related parasitism. In contrast, the hot dry season is usually considered neither favorable nor conducive for arthropod breeding, the heat could might cause egg desiccations and kill larva of arthropods. The high prevalence of avian haemoparasites recorded in the presence study compared to other seasons concurs with similar reports by Igbokwe, et al. [63] who also reported high prevalence of avian haemoparasites during the rainy season in Maiduguri, Nigeria. Similar observation was reported in the semi-arid areas with epidemics of human malaria [99]. The finding of the present study agrees with Hasan, et al. [78] who have reported higher prevalence of avian malaria parasites in the rainy season $(18.3 \%)$ followed by summer $(10.0 \%)$ and winter season $(9.3 \%)$ in Bangladesh. However, the finding of the present study is not in line with similar research conducted by Nath and Bhuiyan, [69] in hilly areas of Bangladesh, who have reported the prevalence of haemoparasites in domestic bird as $60.6 \%$ in summer season, $36.7 \%$ in rainy and $23 \%$ in winter seasons. This finding of the present study was inconsistent with Okanga, et al. [100] who reported higher prevalence in weaver birds of South Africa during late summer $(16.0 \%)$ than winter $(10.0 \%)$ season with significant seasonal difference. In India, Gupta, et al. [101] recorded highest infectivity of pigeon malaria during the summer season $(82.9 \%)$ followed by spring season $(59.4 \%)$ and least in the winter season (42.3\%). Moreover, Senlik, et al. [102] found highest infection rate in autumn (44\%) while the lowest in spring in Iran. These disparities might be associated with the abundance of different arthropods vector population during rainy and cold dry seasons.

Apart from rainfall and differences in habitat composition, differences in prevalence may be influenced by proximity to breeding site for vectors, relative levels of host resistance, local temperature differences, time of collection of samples, effort of sample collection and age of host among the others [103,77]. The mosquitoes, flies and other arthropods breeding rate are increasingly high during rainy seasons in Northeastern, Nigeria. This important role of seasonal impact on vector and the haemoparasites spread could be used as a dynamic tool in the establishment of preventive and control measures for village chicken. It is evident that avian haemoparasites can threaten bird populations and may also impact the survival of their insect vectors [24].

\section{Conclusion}

This study revealed a prevalence of $19.6 \%$ for three (3) genera of haemoparasites of village chickens in Gombe State, which included Plasmodium, Haemoproteus, and Leucocytozoon as single infections and mixed infection with Plasmodium + Haemoproteus. Plasmodium which has been reported worldwide as the major cause of avian malaria in birds was found to be the most prevalent haemoparasites in village chickens in Gombe State. Single infections were more common than mixed infections in the infected village chickens. Prevalence of haemoparasites was significantly higher in male compared to female, as well as in adults compared to the growers. The prevalence was found to be higher in the rainy season compared to the other seasons of the study period.

\section{Recommendations}

It is recommended that similar researches which involve molecular characterization should be conducted to determine the prevalence of haemoparasites species in other village poultry species and wild birds in Gombe State and other parts of Nigeria to further evaluate the epidemiology of the disease. Researches should be conducted to determine the specific vectors transmitting the haemoparasites in the study area.

\section{Acknowledgment}

The authors wish to thank the Director Veterinary Services, Area Veterinary Officers of Gombe State Ministry of Animal Husbandry and Nomadic Affairs and all the 


\section{Open Access Journal of Veterinary Science \& Research}

technical staff of Veterinary Parasitology and Entomology Research Laboratory, Department of Veterinary Parasitology and Entomology, Faculty of Veterinary Medicine, University of Maiduguri for their technical assistance throughout the course of this research.

\section{Conflicts of Interest}

The authors declare that they have no competing interests.

\section{References}

1. Alders RG, Pym RAE (2009) Village poultry: still important to millions eight thousand years after domestication. World's Poultry Science Journal 65(2): 181-190.

2. FAO (2012) How can animal health systems support small-scale poultry producers and traders? Reflections on experience with Highly Pathogenic Avian Influenza (HPAI). Food and Agriculture Organization of the United Nations, Animal Production and Health Working Paper, pp: 1-61.

3. Sehgal RN, Buermann W, Harrigan RJ, Bonneaud C, Loiseau C, et al. (2011) Spatially explicit predictions of blood parasites in a widely distributed African rainforest bird. Proc Biol Sci 278(1708): 1025-1033.

4. Hamer GL, Anderson TK, Berry GE, Makohon Moore AP, Crafton JC, et al. (2013) Prevalence of filarioid nematodes and trypanosomes in American robins and house sparrows in Chicago. Int J Parasitol Parasites Wildl 2: 42-49.

5. Sehgal RNM (2015) Manifold habitat effects on the prevalence and diversity of avian blood parasites. International Journal for Parasitology: Parasites and Wildlife 4(3): 421-430.

6. Dadi-Mamud NJ, Kabir MA, Dibal DM, Rajab MH (2012) Study on the Prevalence of Haemoparasites of Pigeon (Columba livia) In Lapai-Nigeria. International Journal of Applied Biological Research 4(1-2): 121127.

7. Letebrhan G, Aberra M, Sandip B, Gebremedhn B (2015) Product utilization, constraints and opportunities of village chicken under traditional management system in Gantaafeshum District of Eastern Tigray, Ethiopia. Journal of Natural Sciences Research 5(11): 33-38.
8. Ibrahim UI, Lawal JR, El Yuguda AD (2016) Level of Newcastle disease vaccination awareness and its effects on village chicken production in Gombe State, Nigeria. Direct Research Journal of Agriculture and Food Science 4(3): 48-54.

9. Abdullah SH (2013) Prevalence of Blood Parasites in Local Chickens in Qaradagh District, Sulaimani -Iraq. The Iraqi Journal of Veterinary Medicine 37(1): 1721.

10. Krams I, Suraka V, Rattiste K, Abolins Abols M, Krama $\mathrm{T}$, et al. (2012) Comparative analysis reveals a possible immunity-related absence of blood parasites in Common Gulls (Larus canus) and Black-headed Gulls (Chroicocephalus ridibundus). Journal of Ornithology 153(4): 1245-1254.

11. Krams I, Vrublevska J, Cirule D, Kivleniece I, Krama T, et al. (2012) Heterophil/lymphocyte ratios predict the magnitude of humoral immune response to a novel antigen in great tits (Parus major). Comp Biochem Physiol A: Mol Integr Physiol 161(4): 422428.

12. Tostes R, Vashist U, Scopel KKG, Massard CL, Daemon E, et al. (2015) Plasmodium spp. and Haemoproteus spp. infection in birds of the Brazilian Atlantic Forest detected by microscopy and polymerase chain reaction. Pesquisa Veterinaria Brasileira 35(1): 6774.

13. Andreina MP, Ananias AE, Michael MG, Gregory AB, Roberto FA (2011) Haemosporidian infection in captive masked bobwhite quail (Colinus virginianus ridgwayi), an endangered subspecies of the northern bobwhite quail. Journal of Veterinary Parasitology 182: 113-120.

14. Valkiunas G, Palinauskas V, Ilgunas M, Bukauskaite D, Dimitrov D, et al. (2014) Molecular characterization of five widespread avian haemosporidian parasites (Haemosporida), with perspectives on the PCR-based detection of haemosporidians in wildlife. Parasitol Res 113(6): 2251-2263.

15. Valkiunas G, Anwar AM, Atkinson CT, Greiner EC, Paperna I, et al. (2005) What distinguishes malaria parasites from other pigmented haemosporidians?. Trends Parasitol 21(8): 357-358.

16. Paaijmans KP, Read AF, Thomas MB (2009) Understanding the link between malaria risk and 
climate. Proceedings of the National Academy of Sciences of the United States of America 106(33): 13844-13849.

17. Garamszegi LZ (2011) Climate change increases the risk of malaria in birds. Global Change Biology 17(5): 1751-1759.

18. Zamora Vilchis I, Williams SE, Johnson CN (2012) Environmental temperature affects prevalence of blood parasites of birds on an elevation gradient: implications for disease in a warming climate. PLoS ONE 7(6): 1-8.

19. Gupta DK, Jahan N, Gupta N (2011) Distribution pattern of apicomplexan parasites (Sporozoa: Haemosporida) in Columba livia, Gmelin. J Parasit Dis 35(1): 18-22.

20. Zehtindjiev $\mathrm{P}$, Krizanauskiene A, Bensch S, Palinauskas V, Asghar M, et al. (2012) A new morphologically distinct avian malaria parasite that fails detection by established polymerase chain reaction-based protocols for amplification of the cytochrome B gene. J Parasitol 98(3): 657-665.

21. Dimitrov D, Zehtindjiev $P$, Bensch S, Ilieva M, Iezhova $\mathrm{T}$, et al. (2014) Two new species of Haemoproteus Kruse, 1890 (Haemosporida, Haemoproteidae) from European birds, with emphasis on DNA barcoding for detection of haemosporidians in wildlife. Syst Parasitol 87(2): 135-151.

22. Perkins SL (2014) Malaria's many mates: past, present, and future of the systematics of the order Haemosporida. Journal of Parasitology 100(1): 11-25.

23. Gimba FI, Zakaria A, Mugok LB, Siong HC, Jaafar N, et al. (2014) Haemoparasites of Domestic Poultry and Wild Birds in Selangor, Malaysia. Malaysian Journal of Veterinary Research 5(1): 43-51.

24. Ziegyte R, Valkiunas G (2014) Recent advances in vector studies of avian haemosporidian parasites. Ekologija 60(4): 73-83.

25. Valkiunas G (2005) Avian malaria parasites and other haemosporidia. Systematic Biology 54(5): 860-863.

26. Outlaw DC, Ricklefs RE (2011) Rerooting the evolutionary tree of malaria parasites. Proceedings of the National Academy of Sciences of the United States of America 108(32): 13183-13187.
27. Votypka J, Szabova J, Radrova J, Zidkova L, Svobodova M (2012) Trypanosoma culicavium sp. nov., an avian trypanosome transmitted by Culex mosquitoes. Int J Syst Evol Microbiol 62(3): 745-754.

28. Svobodova M, Weidinger K, Peske L, Volf P, Votypka J, et al. (2015) Trypanosomes and haemosporidia in the buzzard (Buteo buteo) and sparrowhawk (Accipiter nisus): factors affecting the prevalence of parasites. Parasitol Res 114(2): 551-560.

29. Silveira P, Belo NO, Rodello D, Pinheiro RT, Braga EM (2010) Microfilariae infection in wild birds from the Brazilian cerrado. J Wildl Dis 46(4): 1305-1309.

30. Valkiunas G, Bensch S, Iezhova TA, Krizanauskiene A, Hellgren O, et al. (2006) Nested cytochrome b polymerase chain reaction diagnostics underestimate mixed infections of avian blood haemosporidian parasites: microscopy is still essential. J Parasitol 92(2): 418-422.

31. Palinauskas V, Valkiunas G, Krizanauskiene A, Bensch $\mathrm{S}$, Bolshakov CV (2009) Plasmodium relictum (lineage P- SGS1): further observation of effects on experimentally infected passeriform birds, with remarks on treatment with Malarone ${ }^{\mathrm{TM}}$. Experimental Parasitology 123(2): 134-139.

32. Braga EM, Silveira P, Belo NO, Valkiunas G (2011) Recent advances in the study of avian malaria: an overview with an emphasis on the distribution of Plasmodium spp in Brazil. Memorias do Instituto Oswaldo Cruz 106: 3-11.

33. Marzal A, de Lope F, Navarro C, Moller AP (2005) Malarial parasites decrease reproductive success: An experimental study in a passerine bird. Oecologia 142(4): 541-545.

34. Tomas G, Merino S, Moreno J, Morales J (2007) Consequences of nest reuse for parasite burden and female health and condition in blue tits, Cyanistes caeruleus. Animal Behaviour 73(5): 805-814.

35. Martinez J, Merino S (2011) Host-parasite interactions under extreme climatic conditions. Current Zoology 57(3): 390-405.

36. Moller AP, Merino S, Soler JJ, Antonov A, Badas EP, et al. (2013) Assessing the effects of climate on hostparasite interactions: a comparative study of 


\section{Open Access Journal of Veterinary Science \& Research}

European birds and their parasites. PloS One 8(12): e82886.

37. la Puente JM, Merino S, Tomas G, Moreno J, Morales J, et al. (2010) The blood parasite Haemoproteus reduces survival in a wild bird: a medication experiment. Biology Letters 6(5): 663-665.

38. Donovan TA, Schrenzel M, Tucker TA, Pessier AP, Stalis IH (2008) Hepatic hemorrhage, hemocoelom, and sudden death due to Haemoproteus infection in passerine birds: eleven cases. J Vet Diagn Invest 20(3): 304-313.

39. Cannell BL, Krasnec KV, Campbell K, Jones HI, Miller RD, et al. (2013) The pathology and pathogenicity of a novel Haemoproteus spp. infection in wild Little Penguins (Eudyptula minor). Veterinary Parasitology 197(1-2): 74-84.

40. de Macchi BM, Miranda FJ, de Souza FS, de Carvalho EC, Albernaz AP, et al. (2013) Chickens treated with a nitric oxide inhibitor became more resistant to Plasmodium gallinaceum infection due to reduced anemia, thrombocytopenia and inflammation. Vet Res 44: 8 .

41. Palinauskas V, Iezhova TA, Krizanauskiene A, Markovets MY, Bensch S, et al. (2013) Molecular characterization and distribution of Haemoproteus minutus (Haemosporida, Haemoproteidae): a pathogenic avian parasite. Parasitol Int 62(4): 358363.

42. Valkiunas G, Kazlauskiene R, Bernotiene R, Palinauskas V, Iezhova TA (2013) Abortive longlasting sporogony of two Haemoproteus species (Haemosporida, Haemoproteidae) in the mosquito Ochlerotatus cantans, with perspectives on haemosporidian vector research. Parasitol Res 112(6): 2159-2169.

43. Valkiunas G, Iezhova TA, Loiseau C, Smith TB, Sehgal RN (2009) New malaria parasites of the subgenus Novyella in African rainforest birds, with remarks on their high prevalence, classification and diagnostics. Parasitol Res 104(5): 1061-1077.

44. Poulsen J, Permin A, Hindsho O, Yelifari L, Nansen P, et al. (2000) Prevalence and distribution of gastrointestinal helminths and haemoparasites in young scavenging chickens in upper eastern region of
Ghana, West Africa. Preventive Veterinary Medicine 4(3-4): 237-245.

45. Permin A, Esmann JB, Hoj CH, Hove T, Mukatirwa S (2002) Ecto, Endo and Haemoparasites in free range chicken in the Gomoronzi District in Zimbabwe. Prev Vet Med 54(3): 213-224.

46. Njunga GR (2003) Ecto-and haemoparasites of chicken in Malawi with emphasis on the effects of the chicken louse, Menacanthus cornutus. MSc thesis. The Royal Veterinary and Agriculture University Denmark.

47. Sadiq NA, Adejinmi JO, Adedokun OA, Fashanu SO, Alimi AA, et al. (2003) Ectoparasites and haemoparasites of indigenous chicken (Gallus domesticus) in Ibadan and environs. Tropical Veterinarian 21(4): 187-191.

48. Sehgal RN, Valkiunas G, Iezhova TA, Smith TB (2006) Blood parasites of chickens in Uganda and Cameroon with molecular descriptions of Leucocytozoon schoutedeni and Trypanosoma gallinarum. J Parasitol 92(6): 1336-1343.

49. Sehgal RN, Hull AC, Anderson NL, Valkiunas G, Markovets MJ, et al. (2006) Evidence for cryptic speciation of Leucocytozoon spp. (Haemosporida, Leucocytozoidae) in diurnal raptors. J Parasitol 92(2): 375-379.

50. Siong HC, Sharma K, Sunil R, Babjee SMA (2010) Assemblages of Ectoparasites and Haemoparasites in the Gallus gallus Complex in Selangor, Malaysia. $5^{\text {th }}$ Seminar on Veterinary Sciences, pp: 5-8.

51. Sabuni ZA, Mbuthia PG, Maingi N, Nyaga PN, Njagi LW, et al. (2011) Prevalence of haemoparasites infection in indigenous chicken in Eastern Province of Kenya. Livestock Research for Rural Development 23(11).

52. Opara MN, Ogbuewu IP, Iwuji CT, Njoku L, Ihesie EK, et al. (2012) Blood characteristics, microbial and gastrointestinal parasites of street pigeons (Columba Livia) in Owerri Imo State, Nigeria. Scientific Journal of Animal Science 1(1): 14-21.

53. Anomymous (2009) Gombe State, Wikipedia free encyclopedia.

54. Adene DF, Oguntade AE (2006) The structure and importance of the commercial and village based 


\section{Open Access Journal of Veterinary Science \& Research}

poultry industry in Nigeria. Poultry production systems. Journal of Poultry Science, pp: 1-109.

55. Cheesbrough M (2000) Protozoology. District laboratory practice in tropical countries. Low-price edition, UK, 1: 134-140.

56. Rukhsana $\mathrm{T}$ (2005) Infectious Haematozoan parasites found in birds of Pakistan. Pakistan Journal of Bioloical Sciences 8(1): 1-5.

57. Zajac AM, Conboy GA (2012) Veterinary Clinical Parasitology. $8^{\text {th }}$ (Edn.), Wiley blackwall. A john wiley and Sons, Inc publication, pp: 186.

58. Valkiunas G, Iezhova TA, Krizanauskiene A, Palinauskas V, Sehgal RN, et al. (2008b) Comparative analysis of microscopy and PCR-based detection methods for blood parasites. J Parasitol 94(6): 13951401.

59. Akinpelu AI (2008) Prevalence and intensity of blood parasites in wild pigeons and doves (family columbidae). Science Alert Journal 109: 114.

60. Thrusfield M (2018) Veterinary Epidemiology. London: Blackwell, Science Ltd $4^{\text {th }}$ (Edn.), Oxford: John Wiley and Sons Ltd, pp: 270-338.

61. Karamba KI, Kawo AH, Dabo NT, Mukhtar MD (2012) A survey of avian malaria parasite in Kano State, Northern Nigeria. International Journal for Biotechnology and Molecular Biology Research 3(1): 8-14.

62. Usmana M, Fabiyia JP, Mohammeda AA, Merab UM, Mahmudaa A, et al. (2012) Ectoparasites and haemoparasites of chickens in sokoto, northwestern Nigeria. Scientific Journal of Zoology 1(3): 74-78.

63. Igbokwe IO, Hassan SU, Faive ZT, Iliya Y, Dagare MJ, et al. (2008) Effect of Plasmodium species infections on packed cell volume of domestic chickens and helmeted guinea fowls in North eastern Nigeria. Animal Research International 5(3): 892-895.

64. Lawal JR, Bello AM, Balami SY, Dauda J, Malgwi KD, et al. (2016) Prevalence of Haemoparasites in village chickens (Gallus gallus domesticus) slaughtered at poultry markets in Maiduguri, Northeastern Nigeria. Journal of Animal Science and Veterinary Medicine 1: $39-45$.
65. Opara NM, Okereke ER, Olayemi OD, Jegede OC (2016) Haemoparasitism of Local and Exotic Chickens Reared in the Tropical Rainforest Zone of Owerri Nigeria. Alexandria Journal of Veterinary Sciences 51(1): 84-89.

66. Etisa E, Chanie M, Tolossa YH (2017) Prevalence of Haemoparasites Infections in Scavenging Indigenous Chickens in and Around Bishoftu. World Applied Sciences Journal 35(2): 302-309.

67. Lutz HL, Hochachka WM, Engel JI, Bell JA, Tkach VV, et al. (2015) Parasite prevalence corresponds to host life history in a diverse assemblage of afrotropical birds and Haemosporidian Parasites. PLoS One 10(4): e0121254.

68. Naqvi MA, Khan MK, Iqbal Z, Rizwan HM, Khan MN, et al. (2017) Prevalence and associated risk factors of haemoparasites, and their effects on hematological profile in domesticated chickens in District Layyah, Punjab, Pakistan. Preventive Veterinary Medicine 1(143): 49-53.

69. Nath TC, Bhuiyan MJU (2017) Haemoprotozoa infection of domestic birds in hilly Areas of Bangladesh. Independent Journal Management Production 8(1): 1-82.

70. Momin MA, Begum N, Dey AR, Paran MS, Alam MZ (2014) Prevalence of blood protozoa in poultry in Tangail, Bangladesh. IOSR Journal of Agriculture Veterinary Sciences 7(7): 55-60.

71. Silva Iturriza A, Ketmaier V, Tiedemann R (2012) Prevalence of avian haemosporidian parasites and their host fidelity in the central Philippine islands. Parasitol Int 61(4): 650-657.

72. Ishtiaq F, Gering E, Rappole JH, Rahmani AR, Jhala YV, et al. (2007) Prevalence and diversity of avian hematozoan parasites in Asia: A regional survey. J Wildl Dis 43(3): 382-398.

73. Hasson RH (2015) Haemosporidians parasites of Gallus domesticus, poultry in Iraq. International Journal of Advanced Research 3(8): 1046-1054.

74. Islam A, Rabbi AKMA, Rahman A, Islam MA, Rahman $\mathrm{MH}$, et al. (2013) Haemoproteus spp. Infection of Domestic Poultry of Bangladesh. VETSCAN 7(2): 8588. 


\section{Open Access Journal of Veterinary Science \& Research}

75. Opara MN, Osowa DK, Maxwell JA (2014) Blood and Gastrointestinal Parasites of Chickens and Turkeys Reared in the Tropical Rainforest Zone of Southeastern Nigeria. Open Journal of Veterinary Medicine 4(12): 308-313.

76. Mbuthia PG, Sabuni ZA, Maingi N, Nyaga PN, Michieka JN, et al. (2011) Prevalence of haemoparasites infection in indigenous chicken in Eastern Province of Kenya. Livestock Research for Rural Development 23(11): 11-19.

77. Nath TC, Bhuiyan MJU, Alam MS (2014) A study on the presence of leucocytozoonosis in pigeon and chicken of hilly districts of Bangladesh. Issues in Biological Sciences and Pharmaceutical Research 2(2): 13-18.

78. Hasan AM, Hossain MS, Anita Rani Dey AR, Alam MZ (2017) Prevalence of malaria parasites in indigenous chickens and ducks in selected districts of Bangladesh. Journal of Bangladesh Agricultural University 15(2): 260-265.

79. Al-Barwari S, Saeed I (2012) The parasitic communities of the rock pigeon Columba livia from Iraq: component and importance. Turkiye Parazitol Derg 36(4): 232-239.

80. Valkiunas G, Iezhova TA, Evans E, Carlson JS, Martinez Gomez JE, et al. (2013) Two new Haemoproteus species (Haemosporida: Haemoproteidae) from columbiform birds. J Parasitol 99(3): 513-521.

81. Lloyd S (1983) Effect of pregnancy and lactation on infection. Veterinary Immunology and Immunopathology 4(1-2): 153-176.

82. Msoffe PLM, Muhairwa AP, Chiwanga GH, Kassuku AA (2010) A study of ecto-and endo-parasites of domestic pigeons in Morogoro Municipality, Tanzania. African Journal of Agricultural Research 5(3): 264-267.

83. Knowles SC, Wood MJ, Alves R, Wilken TA, Bensch S, et al. (2011) Molecular epidemiology of malaria prevalence and parasitaemia in a wild bird population. Mol Ecol 20(5): 1062-1076.

84. Atkinson CT, Samuel MD (2010) Avian malaria Plasmodium relictum in native Hawaiian forest birds: epizootiology and demographic impacts on 'apapane
Himatione sanguinea. Journal of Avian Biology 41: 357-366.

85. van Oers K, Richardson DS, Saether SA, Komdeur J (2010) Reduced blood parasite prevalence with age in the Seychelles Warbler: selective mortality or suppression of infection?. Journal of Ornithology 151(1): 69-77.

86. Castro I, Howe L, Tompkins DM, Barraclough RK, Slaney D (2011) Presence and seasonal prevalence of Plasmodium Spp. in rare endemic New Zealand Passer in (Tieke or Saddleback, Philesturnus Carunculatus). Journal of wildlife Diseases 47(4): 860-867.

87. Scaglione FE, Pregel P, Cannizzo FT, Perez Rodriguez AD, Ferroglio E, et al. (2015) Prevalence of new and known species of haemoparasites in feral pigeons in northwest Italy. Malar J 14: 99.

88. Yeshitila A, Kefelegn T, Mihreteab B (2011) Prevalence of Ectoparasites in Haramaya University Intensive Poultry Farm. Global Veterinaria 7 (3): 264269.

89. Biu AA, Ahmed HA, Konto M, Paul BT (2012) Survey of podoknemidokoptiasis in locally domesticated market chickens (Gallus gallus domesticus) in Maiduguri, Nigeria. Journal of Medical and Applied Biosciences 4: 39-46.

90. Nafyad A, Yimer M, Dawit K, Adem H (2015) Prevalence of Lice and Fleas in Backyard Chickens of Bishoftu Town, Ethiopia. American-Eurasian Journal of Agricultural and Environmental Sciences 15(11): 2136-2142.

91. Thul J, Brien OT (1990) Wood duck hematozoan parasites as biological tags: Development of a population assessment model. Proceedings of the 1988 North American Wood Duck Symposium, University of Missouri, Columbia, Missouri, pp: 323334.

92. Nwoha RIO, Onyeabor A, Igwe KC, Daniel G, Onuekwusi GCO, et al. (2013) Prevalence of Haemoparasites in Livestock in Ikwuano Local Government Area of Abia State. Journal Fisheries and Livestock Production 2: 109.

93. Ukaegbu CO, Nnachi AU, Mawak JD, Igwe CC (2014) Incidence of Concurrent Malaria and Typhoid Fever 
Infections in Febrile Patients in Jos, Plateau State Nigeria. International Journal of Scientific and Technology Research 3(4): 157-161.

94. Kar NP, Kumar A, Singh OP, Carlton JM, Nanda N (2014) A review of malaria transmission dynamics in forest ecosystems. Parasit Vectors 7: 265.

95. Dawaki S, Hesham MAM, Ithoi I, Ibrahim J, Atroosh WM, et al. (2016) Is Nigeria winning the battle against malaria? Prevalence, risk factors and KAP assessment among Hausa communities in Kano State. Malaria Journal 15: 351.

96. Sabina K (2017) Prevalence and Epidemiology of Malaria in Nigeria: A Review. International Journal of Research in Pharmacy and Biosciences 4(8): 10-12.

97. Nas FS, Yahaya A, Ali M (2017) Prevalence of Malaria with Respect to Age, Gender and Socio-Economic Status of Fever Related Patients in Kano City, Nigeria. Greener Journal of Epidemiology Public Health 5(5): 44-49.

98. Obed JD, Imafidor HO (2018) Haemoparasites of Bovine (Sokoto gudali) Species Slaughtered in Port
Harcourt Metropolis, Rivers State, Nigeria. Asian Journal of Biology 5(4): 1-8.

99. Thomson MC, Mason SJ, Phindela T, Connor ST (2005) Use of rainfall and sea surface temperature monitoring for malaria early warning in Botswana. Am J Trop Med Hyg 73(1): 214-221.

100. Okanga S, Cumming GS, Hockey PAR (2013) Avian malaria prevalence and mosquito abundance in the Western Cape, South Africa. Malaria Journal 12: 370.

101. Gupta DK, Jahan N, Gupta N (2011b) New records of Haemoproteus and Plasmodium (Sporozoa: Haemosporida) of rock pigeon (Columba livia) in India. J Parasit Dis 35(2): 155-168.

102. Senlik B, Gulegen E, Akyol V (2005) Prevalence and intensity of Haemoproteus columbae in domestic pigeons. Indian Veterinary Journal 82(9): 998-999.

103. Olayemi OA, Jubril AJ, Adekola AA (2014) Prevalence of Haemoparasites in Village Weaver (Ploceus cucullatus) in Ibadan, Nigeria. Journal World's Poultry Research 4(4): 89-93. 